\title{
A HEPARIN-PRECIPITABLE FRACTION OF HUMAN PLASMA. II. OCCURRENCE AND SIGNIFICANCE OF THE FRACTION IN NORMAL INDIVIDUALS AND IN VARIOUS DISEASE STATES ${ }^{1}$
}

\author{
By RICHARD T. SMITH 2 \\ (From the Pediatric Research Laboratories of the Variety Club Heart Hospital, and the \\ Department of Pediatrics, University of Minnesota Medical School, \\ Minneapolis, Minn.)
}

(Submitted for publication October 22, 1956; accepted December 13, 1956)

The preceding paper (1) describes the isolation and some of the physical chemical characteristics of a fraction of human plasma which precipitates at low temperatures in the presence of heparin. Evidence was presented suggesting that the fraction is closely related to or associated with fibrinogen. This paper is concerned with an account of the method routinely employed for estimating the fraction, and with a presentation of data obtained by this method in normal individuals of all ages, and serially in ill patients. Attempts have been made to correlate the changes in the component with other recognized measurements of inflammatory disease.

\section{MATERIALS AND METHODS}

Method of estimating the heparin-precipitable component. In earlier studies (2) of the heparin-precipitable fraction (HPF), observations were recorded by gross estimation of the amount and density of precipitates appearing in appropriately heparinized plasma after it had remained at $2^{\circ} \mathrm{C}$ for approximately 18 hours. Based upon preliminary experiments, an empirical method of measuring the precipitate was developed early in this investigation. Subsequent studies, presented in detail in the preceding paper, have suggested a number of possible improvements in this technique. However, in order that uniform observations could be made, the procedure described in detail below was adopted and employed unchanged throughout the investigation.

Five ml. of venous blood was taken from the fasting patient into a sterile rubber-stoppered glass tube con-

1 Aided in part by grants from the American Heart Association, the Minnesota Heart Association, and the Graduate School Research Fund of the University of Minnesota.

2 Work performed as Helen Hay Whitney Foundation Research Fellow, and as Senior Investigator, Arthritis and Rheumatism Foundation. taining $0.1 \mathrm{ml}$. heparin solution ${ }^{3}(0.1 \mathrm{ml}$. commercial heparin containing $10 \mathrm{mg}$. per $\mathrm{ml}$. or 100 units per $\mathrm{ml}$. of sodium heparin) and mixed gently by inversion. After centrifugation at room temperature $(2,500 \mathrm{rpm}$ for 15 to 20 minutes) $2.0 \mathrm{ml}$. of supernatant plasma was pipetted into a sterile, acid-cleaned glass tube $(14 \times 100 \mathrm{~mm}$.), covered, and the tube placed in a cold room maintained at $2^{\circ} \mathrm{C}$. The $\mathrm{pH}$ at room temperature of plasmas after these manipulations was usually between 7.8 and 7.9. All subsequent operations during centrifugation and washing of the precipitates were carried out at $2^{\circ} \mathrm{C}$. After standing 16 to 18 hours at this temperature, the tubes were centrifuged at 2,200 rpm for 10 minutes in an International refrigerated centrifuge at $2^{\circ} \mathrm{C}$, the supernatant plasma poured off, and $3.0 \mathrm{ml}$. cold $0.05 \mathrm{M}, \mathrm{pH}$ 7.4 phosphate buffer was added. The precipitate was mixed by thumping the tube repeatedly with the index finger. After recentrifugation the supernate was decanted and the tube inverted to drain for 5 minutes; the precipitate was then rewashed with an additional $3.0 \mathrm{ml}$. of cold buffer. After this second wash, $1.5 \mathrm{ml}$. of the buffer was added to the tube, and the tube placed in a water bath at $37^{\circ} \mathrm{C}$ for 30 minutes. The precipitates rapidly went back into solution. One and five-tenths $\mathrm{ml}$. of biuret reagent (3) was added to the redissolved precipitate, and after 30 minutes the optical density read against an identically run buffer blank at $555 \mathrm{m \mu}$ in a Coleman Jr. spectrophotometer. The protein content of the precipitate from $2.0 \mathrm{ml}$. of plasma was calculated from the optical density by reference to standard curves and expressed as grams per $100 \mathrm{ml}$. plasma. The standard was a solution of crystalline bovine serum albumin, the protein content of which was determined by the micro-Kjeldahl method (4). Results of replicate determinations on pooled plasma samples agreed within $\pm 0.02 \mathrm{gm}$. per cent by the method.

Fibrinogen determination. Plasma fibrinogen was estimated by a modification of the methods of Saifer and Newhouse (5) and Morrison (6) using oxalated plasma.

Two ml. of plasma was placed in a Petri dish containing $5.0 \mathrm{ml}$. of $\mathrm{pH} 6.3$ phosphate-saline buffer solution.

${ }^{3}$ Heparin employed for many of these studies was generously supplied by the Upjohn Company, Kalamazoo, Michigan. 
Four-tenths ml. of a freshly prepared thrombin solution in 0.9 per cent $\mathrm{NaCl}$ ( $8 \mathrm{mg}$. Parke-Davis Thrombin, Topical per $\mathrm{ml}$. saline) was then added with gentle swirling to complete mixing. The clot which had formed after standing one hour at room temperature was washed twice with 0.9 per cent $\mathrm{NaCl}$ and twice with distilled water. After washing, the clot was collected, dried at $90^{\circ} \mathrm{C}$ for 18 hours, and weighed. A factor of 0.83 was applied to correct for occlusion of other plasma proteins, as suggested by Saifer and Newhouse (5), and the final result expressed as grams per $100 \mathrm{ml}$. plasma. Replicate determinations by this method agreed within $\pm 0.02 \mathrm{gm}$. per cent.

Erythrocyte sedimentation rate (ESR). The method of Westergren was employed throughout, using dry "double-oxalate" as the anticoagulant. The values given represent the fall in $\mathrm{mm}$. in one hour at room temperature.

$C$-reactive protein (CRP). CRP was determined on serum specimens by the method described by Anderson and McCarty (7) using C-reactive protein antiserum (CRPA) kindly supplied by Schiefflin and Company.

Muco proteins (M.P.T.). These were determined on serum specimens by the method of Winzler, Devor, Mehl, and Smythe (8), and the results expressed as mg. mucoprotein tyrosine per $100 \mathrm{ml}$. serum.

Clinical material. Patients on the pediatric and medical services of the Variety Club Heart Hospital, in the Children's Rheumatism Clinic of the Heart Hospital, and the general pediatric services of the University of Minnesota Hospitals provided the bulk of clinical material utilized in these studies. A number of selected patients from surgical and obstetrical services were also studied. Serial studies were obtained wherever possible, specimens being taken for HPF, fibrinogen, ESR, CRP, and mucoproteins simultaneously at least twice a week, or as often as the condition of the patient indicated. Graphic charts prepared for each patient were studied in an attempt to correlate serial changes in clinical and routine laboratory findings with the parameters under examination. Representative charts are presented in the text.

Values for healthy individuals were obtained from three sources. The youngest group consisted of children between 2 and 15 years of age undergoing routine precamp physical examinations. The second group, varying in age from 16 to 45 years, was composed of students and faculty of the University of Minnesota undergoing routine physical examinations in the Student Health Service. The third group comprised adults, 46 to 75 years of age, who are being screened by extensive physical and laboratory examinations as a part of a cancer detection study. The author is indebted to Dr. Albert Sullivan of the Department of Surgery, University of Minnesota, for his cooperation in obtaining these specimens. All of the individuals in each group were afebrile, asymptomatic, and had no significant abnormalities on physical examination.

Statistical methods. For analysis of the data, the usual methods have been employed to determine the standard deviation and standard error. Dr. Jacob Bearman of the Department of Biostatistics of the School of Public Health, University of Minnesota, gave valuable advice on statistical analysis of the data, and calculated the regression coefficients.

\section{RESULTS}

\section{HPF levels in healthy individuals}

Levels of heparin-precipitable fraction (HPF) and fibrinogen were determined in 506 healthy individuals. These data are presented in three categories, consisting of individuals from 2 to 15 , 16 to 45 , and 46 to 75 years of age. The frequency distribution of values for male and female patients in each of the three groups is given in Figure 1. It may be seen that the distribution of values for the two older groups of individuals is somewhat skewed toward the higher values. This variation from Gaussian distribution, most striking in the middle age group, reflects, in part at

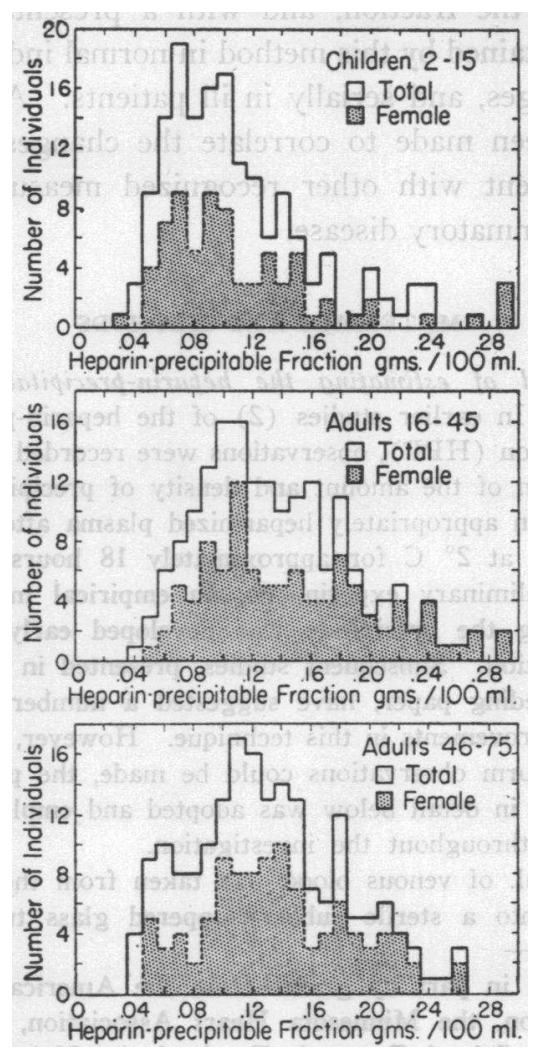

Fig. 1. Frequency Distribution of Normal hPF Values in Three Age Groups Studied

The total area in the distribution represents values for both males and females. The shaded area represents values for females of that distribution. 
TABLE I

Heparin-precipitable fraction and fibrinogen values in normal persons, by age group and sex

\begin{tabular}{|c|c|c|c|c|c|c|c|c|}
\hline \multirow[b]{3}{*}{$\underset{\text { group }}{\text { Age }}$} & \multicolumn{8}{|c|}{ Sex } \\
\hline & \multicolumn{4}{|c|}{ Male } & \multicolumn{4}{|c|}{ Female } \\
\hline & Number & $\begin{array}{l}\text { Mean } \\
\text { gm. \% }\end{array}$ & $\begin{array}{l}\text { Standard } \\
\text { deviation }\end{array}$ & $\begin{array}{l}\text { Standard } \\
\text { error mean }\end{array}$ & Number & $\begin{array}{l}\text { Mean } \\
\text { gm. \% }\end{array}$ & $\begin{array}{l}\text { Standard } \\
\text { deviation }\end{array}$ & $\begin{array}{l}\text { Standard } \\
\text { error mean }\end{array}$ \\
\hline \multicolumn{9}{|c|}{ (A) Heparin-precipitable fraction } \\
\hline $\begin{array}{r}3-15 \\
16-45 \\
46-75\end{array}$ & $\begin{array}{l}69 \\
80 \\
85\end{array}$ & $\begin{array}{l}0.101 \\
0.129 \\
0.121\end{array}$ & $\begin{array}{l}0.043 \\
0.049 \\
0.051\end{array}$ & $\begin{array}{l}0.005 \\
0.006 \\
0.006\end{array}$ & $\begin{array}{r}70 \\
99 \\
103\end{array}$ & $\begin{array}{l}0.104 \\
0.144 \\
0.137\end{array}$ & $\begin{array}{l}0.042 \\
0.059 \\
0.053\end{array}$ & $\begin{array}{l}0.005 \\
0.006 \\
0.005\end{array}$ \\
\hline \multicolumn{9}{|c|}{ (B) Fibrinogen } \\
\hline $\begin{array}{r}3-15 \\
16-45 \\
46-75\end{array}$ & $\begin{array}{l}55 \\
90 \\
85\end{array}$ & $\begin{array}{l}0.219 \\
0.199 \\
0.243\end{array}$ & $\begin{array}{l}0.038 \\
0.046 \\
0.056\end{array}$ & $\begin{array}{l}0.005 \\
0.005 \\
0.006\end{array}$ & $\begin{array}{r}72 \\
101 \\
94\end{array}$ & $\begin{array}{l}0.227 \\
0.210 \\
0.229\end{array}$ & $\begin{array}{l}0.043 \\
0.046 \\
0.066\end{array}$ & $\begin{array}{l}0.005 \\
0.005 \\
0.007\end{array}$ \\
\hline
\end{tabular}

least, the higher range of values obtained for females. Values for the youngest group fell into a narrower range, and values for male and female patients showed similar distribution.
Table I A summarizes the mean values for HPF by age group and sex. The mean HPF values for males and females differed slightly but significantly $(P=<0.001)$ in the two older groups. The

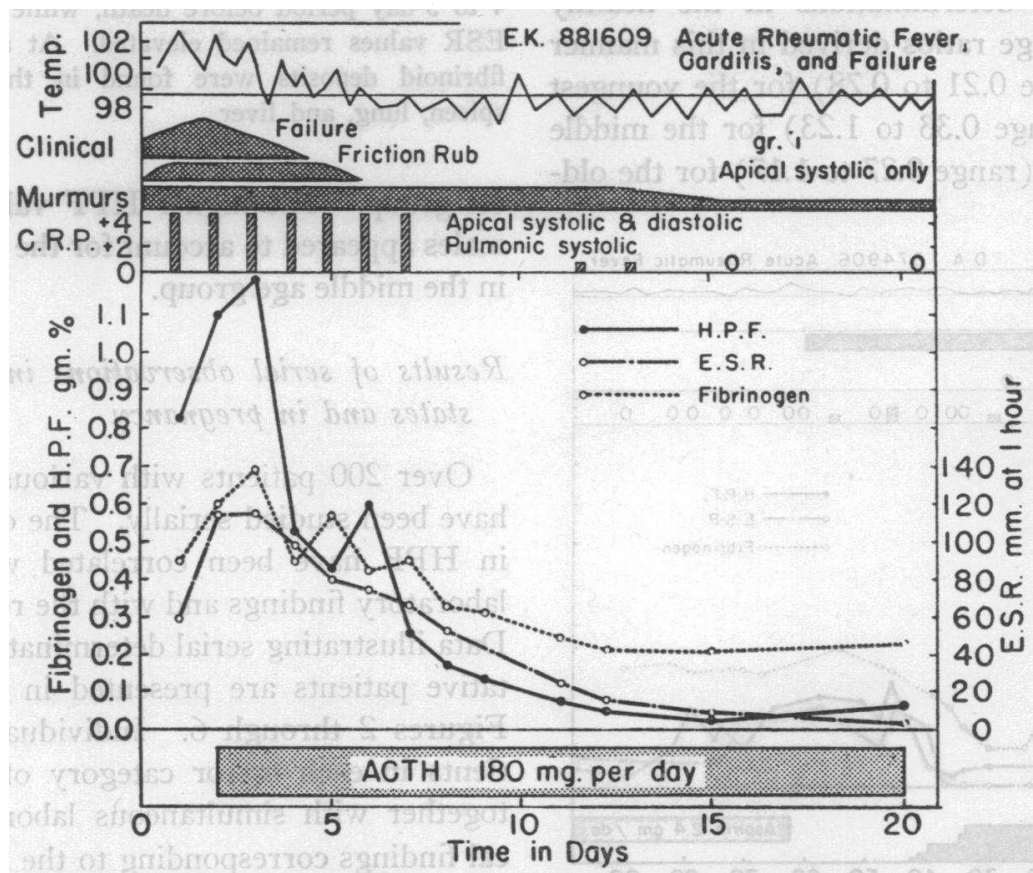

Fig. 2. Chart Depicting Serial Changes in the Clinical Course and Laboratory Features of Severe Acute Rheumatic Fever with Carditts and Failure in a 12-Year-Old Gird

The clinical findings are presented schematically at the top of the chart, the C-reactive protein in the center, and the HPF (solid line), fibrinogen (dotted line) and ESR (dot-dash line) are given below. HPF reached 1.38 gm. per cent initially and fell abruptly to low levels with ACTH treatment. Fibrinogen and ESR, although elevated initially, fell more gradually to normal levels. Note that a high initial HPF/fibrinogen ratio decreased abruptly during recovery to the low values characteristic of normal individuals. 
apparent difference in the mean values of children and adults, however, may be due to differences other than those determined by age alone, since the groups were composed of individuals of entirely different economic, social, and nutritional status.

Since it was evident early in this investigation that HPF resembled fibrinogen in certain respects, this protein was assayed simultaneously with HPF. The mean value for fibrinogen in 506 healthy individuals, given in section B of Table I, was approximately $0.22 \mathrm{gm}$. per cent, the oldest group of males having slightly higher values than the other groups. This mean fibrinogen value is somewhat lower than some normal data (9), but comparable to those of Saifer and Newhouse (5). Since the data (see below) on ill patients appeared to lend significance to changes in the ratio $H P F /$ fibrinogen, this value was calculated for each pair of determinations in the healthy groups; the average ratios derived in this manner were 0.458 (range 0.21 to 0.78 ) for the youngest group, 0.709 (range 0.33 to 1.23 ) for the middle group, and 0.568 (range 0.27 to 1.17 ) for the old-

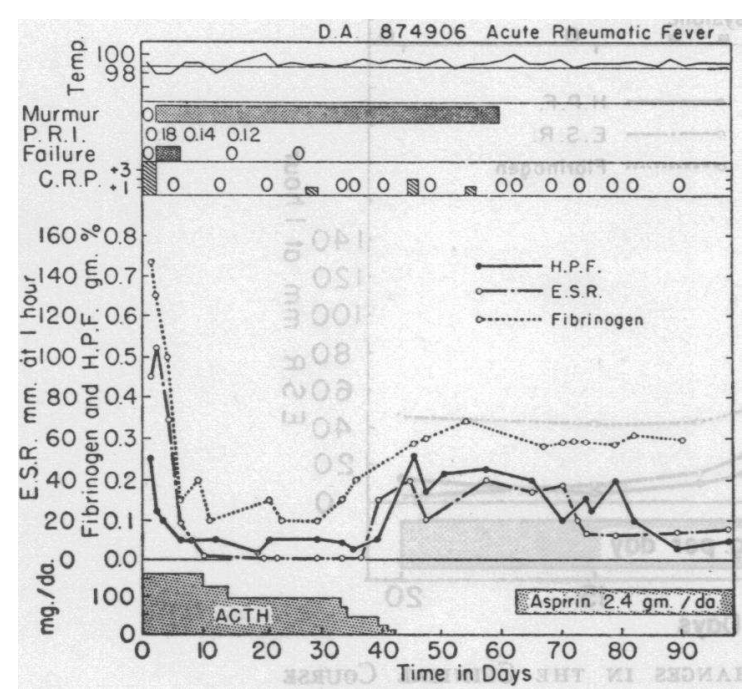

Fig. 3. Chart Representing Serial Clinical and Laboratory Changes in an 8-Year-Old Boy with Severe Rheumatic Fever Who Had Been Partially Treated with aCTH Prior to Admission

Note that HPF became elevated during period of laboratory "rebound" after ACTH withdrawal, accompanied by slight fever, appearance of C-reactive protein in the serum and increase in sedimentation rate. Fibrinogen level elevation preceded the HPF rise by about 5 days. Return of these values to normal followed salicylate therapy.

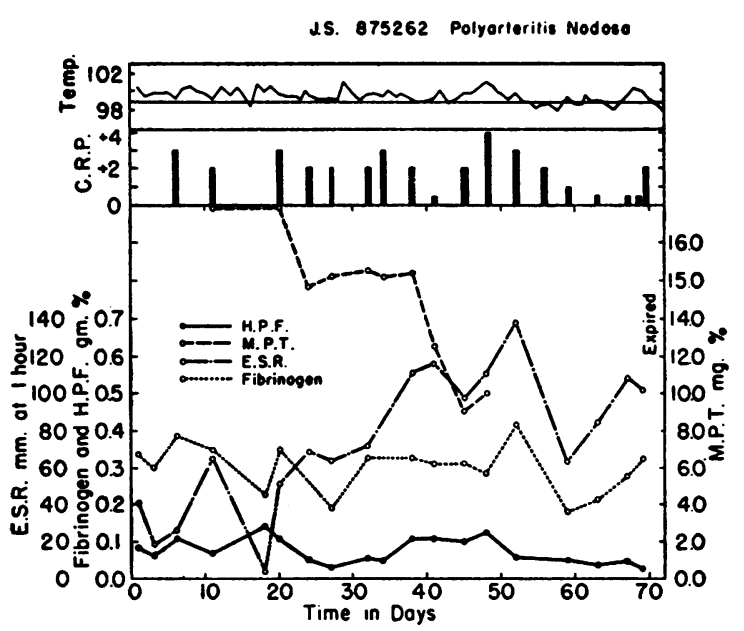

Fig. 4. J. S. Seriar Changes in HPF, Fibrinogren, aNd ESR Corretatem with CRP aNd Clinicar Findings in a 9-Year-Old Boy with Fulminating PolyARTERITIS

Note that HPF fell progressively to low levels in the 4 to 5-day period before death, while the fibrinogen and ESR values remained elevated. At autopsy widespread fibrinoid deposits were found in the kidney, adrenal, spleen, lung, and liver.

est group. The higher HPF values found in females appeared to account for the high ratio values in the middle age group.

Results of serial observations in various disease states and in pregnancy

Over 200 patients with various types of illness have been studied serially. The observed changes in HPF have been correlated with clinical and laboratory findings and with the results of therapy. Data illustrating serial determinations in representative patients are presented in graphic form in Figures 2 through 6 . Individual values for patients in each major category of illness studied, together with simultaneous laboratory and clinical findings corresponding to the HPF values, are given in Tables II through V. Where serial observations are available, the value given in the tables represents the initial HPF value in the series. Since the patient was usually acutely ill when first studied, this value usually represents the highest measured during the series.

Acute rheumatic fever. Data on forty children with acute rheumatic fever studied serially during the course of their disease are presented in Table II. Figures 2 and 3 illustrate the serial changes 


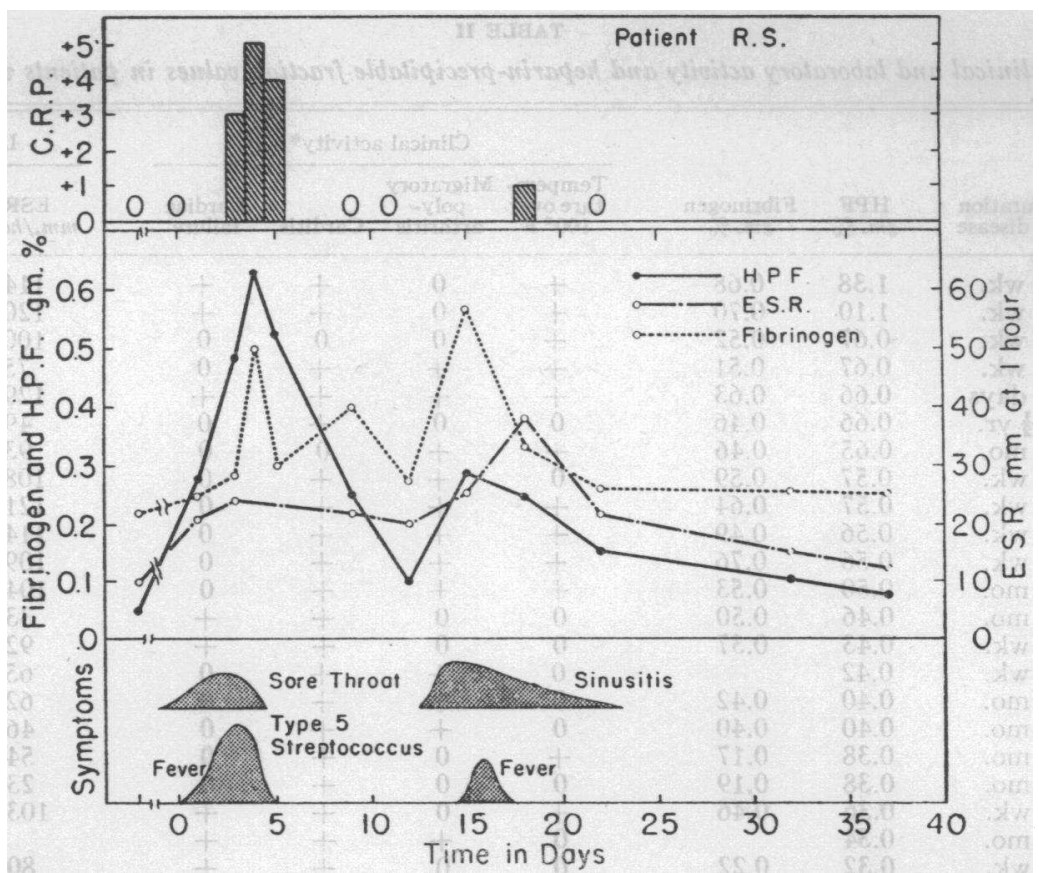

Fig. 5. Serial Changes in HPF, Fibrinogen, and ESR in a 30Year-Old Male During the Course of Group A, Type 5, Streptococcal Pharyngttis

Normal HPF values had been obtained periodically during the preceding six-month period. Note rapidity of HPF elevation and return to normal in relation to clinical course.

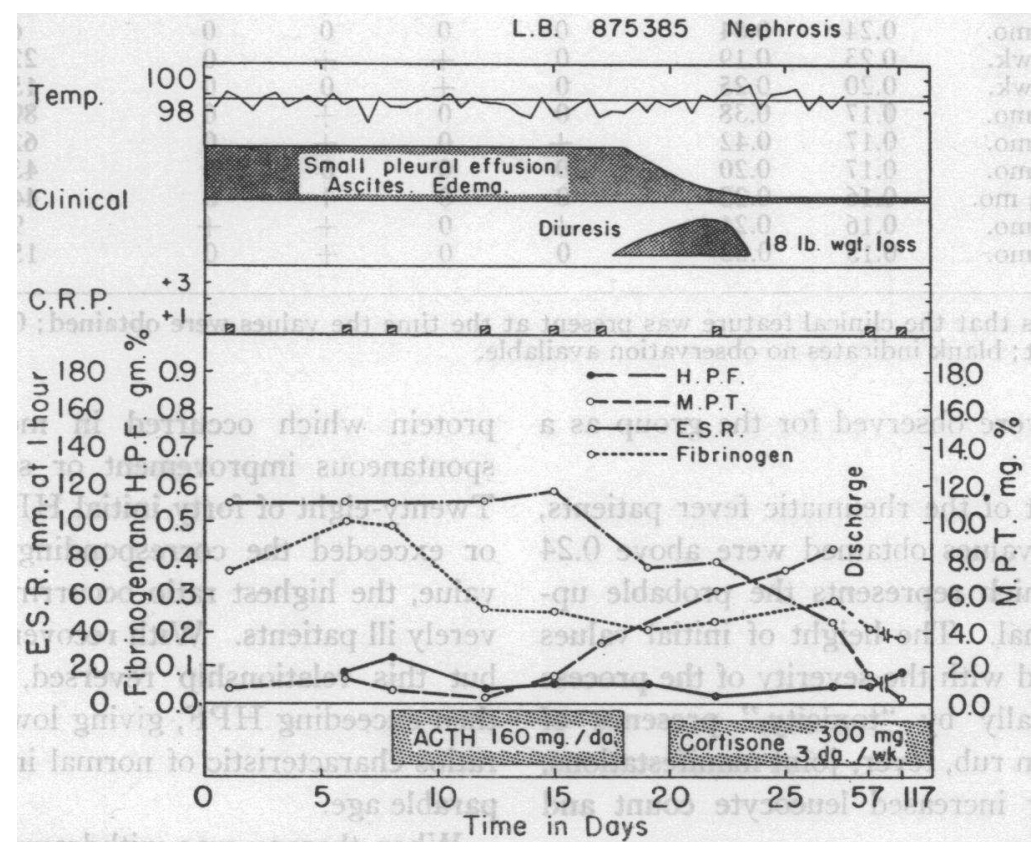

Fig. 6. Serial Observations of HPF, Fibrinogen, ESR, and Mucoproteins (M.P.T.) DuRING an ACTH-INduCEd DiURESIS IN AN 8-YearOzd Boy wITH NepHrosis

Note that despite changes in fibrinogen, ESR, and mucoprotein during the diuresis, the HPF levels remained relatively stationary and low. 
TABLE II

Relation between clinical and laboratory activity and heparin-precipitable fraction values in patients with rheumatic fever

\begin{tabular}{|c|c|c|c|c|c|c|c|c|c|c|c|}
\hline \multirow[b]{2}{*}{ Patient } & \multirow[b]{2}{*}{ Age } & \multirow[b]{2}{*}{$\begin{array}{l}\text { Duration } \\
\text { of disease }\end{array}$} & \multirow[b]{2}{*}{$\underset{g m . \%}{\operatorname{HPF}}$} & \multirow[b]{2}{*}{$\begin{array}{c}\text { Fibrinogen } \\
\text { gm.\% }\end{array}$} & \multicolumn{4}{|c|}{ Clinical activity* } & \multicolumn{3}{|c|}{ Laboratory activity } \\
\hline & & & & & $\begin{array}{l}\text { Tempera- } \\
\text { ture overer } \\
100^{\circ} \mathrm{F}\end{array}$ & $\begin{array}{l}\text { Migratory } \\
\text { poly- } \\
\text { arthritis }\end{array}$ & Carditis & $\begin{array}{l}\text { Cardiac } \\
\text { failure }\end{array}$ & $\underset{m m . / h o u r}{\text { ESR }}$ & CRP & $\begin{array}{l}\text { Mucoprotein } \\
\text { mg. tyrosine } \\
\text { per } 100 \mathrm{ml} \text {. }\end{array}$ \\
\hline $\begin{array}{r}1 \\
2 \\
3 \\
4 \\
5 \\
6 \\
7 \\
8 \\
9 \\
10 \\
11 \\
12 \\
13 \\
14 \\
15 \\
16 \\
17 \\
18 \\
19 \\
20 \\
21 \\
22 \\
23 \\
24 \\
25 \\
26 \\
27 \\
28 \\
29 \\
30 \\
31 \\
32 \\
33 \\
34 \\
35 \\
36 \\
37 \\
38 \\
39 \\
40\end{array}$ & $\begin{array}{r}12 \\
8 \\
11 \\
14 \\
14 \\
77 \\
16 \\
14 \\
7 \\
7 \\
9 \\
12 \\
4 \\
5 \\
30 \\
24 \\
13 \\
15 \\
10 \\
14 \\
9 \\
11 \\
7 \\
4 \\
7 \\
11 \\
12 \\
13 \\
4 \\
12 \\
9 \\
12 \\
38 \\
18 \\
12 \\
5 \\
7 \\
11 \\
13 \\
7\end{array}$ & 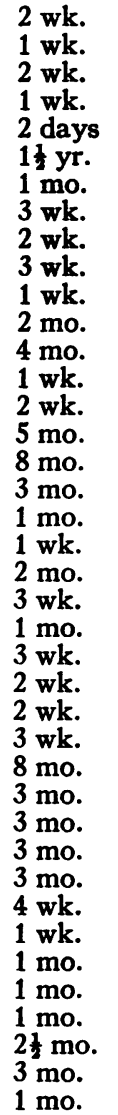 & $\begin{array}{l}1.38 \\
1.10 \\
0.67 \\
0.67 \\
0.66 \\
0.66 \\
0.65 \\
0.57 \\
0.57 \\
0.56 \\
0.56 \\
0.50 \\
0.46 \\
0.43 \\
0.42 \\
0.40 \\
0.40 \\
0.38 \\
0.38 \\
0.36 \\
0.34 \\
0.32 \\
0.31 \\
0.30 \\
0.30 \\
0.27 \\
0.27 \\
0.27 \\
0.26 \\
0.26 \\
0.26 \\
0.24 \\
0.23 \\
0.20 \\
0.17 \\
0.17 \\
0.17 \\
0.16 \\
0.16 \\
0.15\end{array}$ & $\begin{array}{l}0.68 \\
0.70 \\
0.52 \\
0.51 \\
0.63 \\
0.46 \\
0.46 \\
0.59 \\
0.64 \\
0.49 \\
0.76 \\
0.53 \\
0.50 \\
0.37 \\
\\
0.42 \\
0.40 \\
0.17 \\
0.19 \\
0.46 \\
0.22 \\
0.45 \\
0.38 \\
0.29 \\
0.28 \\
0.29 \\
0.51 \\
0.47 \\
0.37 \\
0.74 \\
0.34 \\
0.19 \\
0.25 \\
0.38 \\
0.42 \\
0.20 \\
0.28 \\
0.21 \\
0.22\end{array}$ & $\begin{array}{l}+ \\
+ \\
+ \\
+ \\
+ \\
0 \\
+ \\
0 \\
+ \\
+ \\
+ \\
+ \\
0 \\
0 \\
0 \\
0 \\
0 \\
+ \\
0 \\
+ \\
0 \\
0 \\
+ \\
0 \\
+ \\
0 \\
0 \\
0 \\
0 \\
0 \\
0 \\
0 \\
0 \\
0 \\
0 \\
+ \\
0 \\
0 \\
+ \\
0\end{array}$ & $\begin{array}{l}0 \\
0 \\
0 \\
+ \\
+ \\
0 \\
+ \\
+ \\
+ \\
+ \\
+ \\
+ \\
0 \\
0 \\
+ \\
+ \\
+ \\
0 \\
0 \\
0 \\
+ \\
0 \\
+ \\
+ \\
+ \\
0 \\
0 \\
0 \\
+ \\
0 \\
+ \\
0 \\
+ \\
+ \\
0 \\
0 \\
0 \\
0 \\
0 \\
0\end{array}$ & $\begin{array}{l}+ \\
+ \\
0 \\
+ \\
+ \\
+ \\
0 \\
+ \\
+ \\
+ \\
+ \\
+ \\
+ \\
+ \\
+ \\
+ \\
+ \\
+ \\
+ \\
+ \\
+ \\
+ \\
+ \\
+ \\
+ \\
+ \\
+ \\
+ \\
+ \\
+ \\
0 \\
+ \\
0 \\
+ \\
+ \\
0 \\
+ \\
+ \\
+\end{array}$ & $\begin{array}{l}+ \\
+ \\
0 \\
0 \\
+ \\
0 \\
0 \\
0 \\
0 \\
0 \\
0 \\
0 \\
+ \\
+ \\
0 \\
0 \\
0 \\
0 \\
0 \\
+ \\
+ \\
+ \\
+ \\
+ \\
+ \\
0 \\
0 \\
0 \\
0 \\
0 \\
0 \\
0 \\
0 \\
0 \\
0 \\
0 \\
0 \\
0 \\
+ \\
0\end{array}$ & $\begin{array}{r}114 \\
120 \\
100 \\
75 \\
129 \\
49 \\
93 \\
108 \\
121 \\
114 \\
109 \\
104 \\
33 \\
92 \\
65 \\
62 \\
46 \\
54 \\
23 \\
103 \\
\\
80 \\
39 \\
122 \\
49 \\
18 \\
47 \\
103 \\
56 \\
36 \\
93 \\
6 \\
22 \\
15 \\
89 \\
62 \\
43 \\
44 \\
9 \\
15\end{array}$ & $\begin{array}{l}4+ \\
4+ \\
4+ \\
4+ \\
4+ \\
3+ \\
2+ \\
2+ \\
4+ \\
4+ \\
3+ \\
4+ \\
\\
4+ \\
3+ \\
0 \\
2+ \\
1+ \\
3+ \\
1+ \\
2+ \\
2+ \\
2+ \\
2+ \\
2+ \\
0 \\
0 \\
1+ \\
4+ \\
0 \\
4+ \\
0 \\
1+ \\
0 \\
0 \\
2+ \\
0 \\
0 \\
2+ \\
0\end{array}$ & $\begin{array}{r}7.30 \\
6.30 \\
5.80 \\
7.80 \\
5.10 \\
9.30 \\
8.80 \\
7.50 \\
10.65 \\
9.35 \\
8.20 \\
2.58 \\
8.00 \\
6.68 \\
8.20 \\
\\
16.00 \\
7.10 \\
7.90 \\
6.08 \\
4.10 \\
10.70 \\
7.80 \\
4.60 \\
3.40 \\
6.50\end{array}$ \\
\hline
\end{tabular}

* "+" indicates that the clinical feature was present at the time the values were obtained; 0 indicates that these features were absent; blank indicates no observation available.

in HPF which were observed for the group as a whole.

In all but eight of the rheumatic fever patients, the initial HPF values obtained were above 0.24 gm. per cent, which represents the probable upper limit of normal. The height of initial values roughly correlated with the severity of the process as gauged clinically by "toxicity," presence of pericardial friction rub, fever, joint manifestations, and by markedly increased leucocyte count and ESR.

The patient whose clinical course is shown in Figure 2 illustrates the reversal of the relationship between the absolute values for HPF and clottable protein which occurred in most patients with spontaneous improvement or successful therapy. Twenty-eight of forty initial HPF values equalled or exceeded the corresponding clottable protein value, the highest ratio occurring in the most severely ill patients. With recovery both values fell, but this relationship reversed, clottable protein then exceeding HPF, giving low $\mathrm{HPF} /$ fibrinogen ratios characteristic of normal individuals of comparable age.

When therapy was withdrawn abruptly, resulting in the so-called "rebound" phenomenon, HPF values again rose above normal. An example of this type of change is illustrated in Figure 3. 
"Collagen" diseases. The hypothesis that the heparin-precipitable component might represent a fibrinoid "precursor" $(1,2)$ led to serial examination in patients with diseases in which fibrinoid deposition represents significant histopathological change. Table III summarizes the representative values obtained in patients with juvenile and adult forms of rheumatoid arthritis, acute lupus erythematosus disseminatus, scleroderma, dermatomyositis, polyarteritis, and anaphylactoid purpura. $\mathrm{Pa}$ tients with rheumatoid arthritis, like the rheumatic fever group, had high HPF values when their disease was most severe, with high fever, joint involvement, leucocytosis, and the characteristic skin rash. When alleviation of these manifestations was brought about by cortisone or salicylate administration, or when spontaneous remissions occurred, the values returned to normal or low levels.

On the other hand, the patients with disseminated lupus erythematosus and polyarteritis were found to have HPF values in the normal range for age, or even below normal levels, in spite of high fever, severe illness, elevated clottable protein values, strongly positive CRP, extremely high ESR and mucoprotein values. In one patient having polyarteritis (Figure 4) HPF values fell to extremely low levels while clottable protein values remained relatively unchanged during the week prior to demise. At autopsy widespread vascular lesions with prominent deposition of fibrinoid were found.

Infectious diseases. High HPF levels were found in patients with various acute bacterial infections, as shown in Table IV.

Marked initial elevation of HPF values was observed in patients having meningitis due to $H$. influenza, Str. pneumoniae, or Niesseria intracellularis, and in those having streptococcal pharyngitis (Figure 5), urinary tract infection, bacterial endocarditis, and cryptococcosis. These high initial HPF levels returned to normal with effective antibiotic therapy. Again, the reversal in the relationship of HPF and clottable protein as recovery ensued was found.

In contrast to the elevation of HPF observed in acute bacterial infections, patients with common viral infections studied were found to have normal or only slightly elevated HPF values.

Neoplastic diseases. Nineteen patients of various ages with neoplastic disease of various types were studied. The values obtained are summarized in Table V. High values were found in patients whose lesions were extensive or widely dis-

TABLE III

Heparin-precipitable fraction in patients with various "collagen" disorders

\begin{tabular}{|c|c|c|c|c|c|c|}
\hline Patient & Age & Disease and activity & $\underset{g m . \%}{\mathbf{H P F}}$ & $\begin{array}{l}\text { Fibrinogen } \\
\boldsymbol{g m . \%}\end{array}$ & $\underset{m m . / h r}{\operatorname{ESR}}$ & CRP \\
\hline \multirow[t]{2}{*}{$\begin{array}{l}1 \\
2 \\
3 \\
4 \\
5 \\
6\end{array}$} & \multirow[t]{2}{*}{$\begin{array}{r}5 \\
9 \\
4 \\
1 \\
50 \\
22\end{array}$} & \multirow{3}{*}{$\begin{array}{l}\text { Severe juvenile rheumatoid arthritis } \\
\text { Severe juvenile rheumatoid arthritis } \\
\text { Severe juvenile rheumatoid arthritis } \\
\text { Severe juvenile rheumatoid arthritis } \\
\text { Severe chronic rheumatoid arthritis } \\
\text { Severe rheumatoid arthritis- } \\
\text { steroid treatment } \\
\text { Severe juvenile rheumatoid arthritis- } \\
\text { salicylate treatment }\end{array}$} & $\begin{array}{l}0.73 \\
0.52 \\
0.47 \\
0.47 \\
0.44\end{array}$ & $\begin{array}{l}0.66 \\
0.39 \\
0.43 \\
0.36 \\
0.71\end{array}$ & $\begin{array}{r}91 \\
84 \\
104 \\
130 \\
113\end{array}$ & $\begin{array}{l}3+ \\
4+ \\
2+ \\
4+ \\
4+\end{array}$ \\
\hline & & & 0.38 & 0.42 & 104 & $3+$ \\
\hline 7 & 6 & & 0.33 & 0.64 & 54 & $4+$ \\
\hline \multirow{3}{*}{$\begin{array}{r}8 \\
9 \\
10 \\
11 \\
12\end{array}$} & \multirow[t]{2}{*}{$\begin{array}{l}15 \\
12 \\
21 \\
32\end{array}$} & \multirow{3}{*}{$\begin{array}{l}\text { Acute disseminated lupus erythematosus } \\
\text { Acute disseminated lupus erythematosus } \\
\text { Acute disseminated lupus erythematosus } \\
\text { Acute disseminated lupus erythematosus- } \\
\text { cortisone treatment } \\
\text { Acute disseminated lupus erythematosus- } \\
\text { cortisone treatment }\end{array}$} & $\begin{array}{l}0.32 \\
0.16 \\
0.22\end{array}$ & $\begin{array}{l}0.64 \\
0.51 \\
0.21\end{array}$ & $\begin{array}{r}142 \\
123 \\
3\end{array}$ & $\begin{array}{l}4+ \\
4+ \\
0\end{array}$ \\
\hline & & & 0.08 & 0.15 & & $2+$ \\
\hline & & & 0.08 & 0.32 & 103 & $2+$ \\
\hline 13 & 9 & Severe dermatomyositis- & & & & \\
\hline $\begin{array}{l}14 \\
15 \\
16 \\
17 \\
18\end{array}$ & $\begin{array}{r}5 \\
4 \\
12 \\
9 \\
28\end{array}$ & $\begin{array}{l}\text { Schonlein-Henoch purpura } \\
\text { Dermatomyositis } \\
\text { Scleroderma } \\
\text { Fulminating polyarteritis } \\
\text { Fulminating polyarteritis }\end{array}$ & $\begin{array}{l}0.35 \\
0.54 \\
0.22 \\
0.04 \\
0.18\end{array}$ & $\begin{array}{l}0.20 \\
0.58 \\
0.25 \\
0.32 \\
0.43\end{array}$ & $\begin{array}{r}54 \\
85 \\
49 \\
103 \\
63\end{array}$ & $\begin{array}{l}2+ \\
1+ \\
1+ \\
2+ \\
3+\end{array}$ \\
\hline
\end{tabular}


TABLE IV

Heparin-precipitable fraction values in patients with various infections

\begin{tabular}{|c|c|c|c|c|c|c|c|c|}
\hline Patient & Age & Type of infection & Micro-organism & Duration & $\underset{8 m . \%}{\text { HPF }}$ & $\begin{array}{l}\text { Fibringgen } \\
\text { gm. \% }\end{array}$ & $\underset{m m . / h r}{\operatorname{ESR}}$ & $\begin{array}{c}\text { C-reactive } \\
\text { protein }\end{array}$ \\
\hline $\begin{array}{r}1 \\
2 \\
3 \\
4 \\
5 \\
6 \\
7 \\
8 \\
9 \\
10 \\
11\end{array}$ & $\begin{array}{rl}3 & \mathrm{yr} . \\
22 \mathrm{mo} . \\
16 \mathrm{mo} . \\
1 \mathrm{yr} . \\
1 \mathrm{yr} . \\
6 \mathrm{yr} . \\
10 \mathrm{yr} . \\
3 \mathrm{yr} . \\
3 \mathrm{yr} . \\
14 \mathrm{yr} . \\
10 \mathrm{yr} .\end{array}$ & $\begin{array}{l}\text { Meningitis-septicemia } \\
\text { Meningitis-septicemia } \\
\text { Meningitis-septicemia } \\
\text { Meningitis-septicemia } \\
\text { Meningitis-septicemia } \\
\text { Meningitis } \\
\text { Meningitis-septicemia } \\
\text { Meningitis-septicemia } \\
\text { Meningitis-septicemia } \\
\text { Meningitis } \\
\text { Meningitis (partially } \\
\text { treated) }\end{array}$ & $\begin{array}{l}H . \text { infiuensa } \\
H . \text { influensa } \\
H . \text { infiucusa } \\
H . \text { influenza } \\
H . \text { influensa } \\
N . \text { intracellularis } \\
N . \text { intracellularis } \\
N . \text { intracellularis } \\
N . \text { intracellularis } \\
D . \text { pneumoniae } \\
D . \text { pnewmoniae }\end{array}$ & $\begin{array}{c}1 \text { day } \\
4 \text { days } \\
10 \text { days } \\
6 \text { days } \\
6 \text { days } \\
2 \text { days } \\
3 \text { days } \\
1 \text { wk. } \\
1 \text { day } \\
1 \text { wk. } \\
1 \text { wk. }\end{array}$ & $\begin{array}{l}1.08 \\
0.77 \\
0.36 \\
0.31 \\
0.31 \\
0.83 \\
0.69 \\
0.38 \\
0.33 \\
0.40 \\
0.23\end{array}$ & $\begin{array}{l}0.88 \\
0.53 \\
0.48 \\
0.35 \\
0.38 \\
0.36 \\
0.54 \\
0.51 \\
0.78 \\
0.53 \\
0.47\end{array}$ & $\begin{array}{r}104 \\
123 \\
108 \\
33 \\
81 \\
40 \\
53 \\
109 \\
71 \\
106\end{array}$ & $\begin{array}{l}4+ \\
4+ \\
3+ \\
3+ \\
1+ \\
3+ \\
3+ \\
3+ \\
4+ \\
4+ \\
0\end{array}$ \\
\hline 12 & 8 yr. & Pharyngitis & Str. Remolyticus, & 6 days & 0.68 & 0.37 & 51 & $3+$ \\
\hline 13 & 30 yr. & Pharyngitis & Str. hemolyticus, & 4 days & 0.65 & 0.50 & 22 & $4+$ \\
\hline 14 & 16 yr. & Scarlet fever & Str. hemolyticus, & 5 days & 0.57 & 0.31 & & \\
\hline 15 & $1 \frac{\mathrm{yr}}{\mathrm{y}}$ & Pharyngitis & $\begin{array}{l}\text { Str. hemolyticus, } \\
\text { Group A }\end{array}$ & 3 days & 0.41 & 0.42 & 34 & 0 \\
\hline $\begin{array}{l}16 \\
17\end{array}$ & $\begin{array}{l}7 \mathrm{yr} . \\
13 \mathrm{yr} .\end{array}$ & $\begin{array}{l}\text { Mastoiditis, chronic } \\
\text { Bronchiectasis, } \\
\text { chronic }\end{array}$ & $\begin{array}{l}\text { Various } \\
\text { Various }\end{array}$ & $\begin{array}{l}2 \mathrm{yr} . \\
10 \mathrm{yr} .\end{array}$ & $\begin{array}{l}0.22 \\
0.29\end{array}$ & $\begin{array}{l}0.35 \\
0.35\end{array}$ & $\begin{array}{l}98 \\
13\end{array}$ & $\begin{array}{l}\mathbf{0} \\
\mathbf{0}\end{array}$ \\
\hline 18 & 4 yr. & $\begin{array}{l}\text { Acute and chronic uri- } \\
\text { nary tract infection }\end{array}$ & E. coli & 3 days & 0.87 & 0.58 & 106 & $4+$ \\
\hline 19 & 4 yr. & $\begin{array}{l}\text { Acute urinary tract } \\
\text { infection }\end{array}$ & E. coli & 1 day & 0.30 & & 30 & $4+$ \\
\hline 20 & $14 \mathrm{yr}$. & $\begin{array}{l}\text { Subacute bacterial } \\
\text { endocarditis }\end{array}$ & Str. viridans & $2 \mathrm{mo}$. & 0.60 & 0.42 & 110 & $3+$ \\
\hline 21 & $14 \mathrm{yr}$. & Acute appendicitis & & 1 day & 0.27 & 0.40 & 57 & $3+$ \\
\hline 22 & 4 yr. & Generalized infection & $\begin{array}{l}\text { Cryptococcus } \\
\text { neoformans }\end{array}$ & Unknown & 0.60 & 0.54 & 64 & $4+$ \\
\hline 23 & $9 \mathrm{yr}$. & $\begin{array}{l}\text { Polycythemia due to } \\
\text { cong. H. D.; acute } \\
\text { pulmonary infection }\end{array}$ & $\begin{array}{l}\text { Histoplasma } \\
\text { capsulatum }\end{array}$ & 3 wk. & 0.21 & 0.14 & 0 & $4+$ \\
\hline $\begin{array}{l}24 \\
25 \\
26 \\
27\end{array}$ & $\begin{array}{l}6 \mathrm{yr} . \\
5 \text { yr. } \\
3 \text { yr. } \\
6 \text { yr. }\end{array}$ & $\begin{array}{l}\text { Measles } \\
\text { Measles } \\
\text { Common cold } \\
\text { Encephalitis }\end{array}$ & Mumps & $\begin{array}{r}44 \text { days } \\
6 \text { days } \\
2 \text { days } \\
4 \text { days }\end{array}$ & $\begin{array}{l}0.32 \\
0.16 \\
0.15 \\
0.18\end{array}$ & $\begin{array}{l}0.38 \\
0.29 \\
0.24 \\
0.20\end{array}$ & $\begin{array}{l}42 \\
38\end{array}$ & $1+$ \\
\hline
\end{tabular}

TABLE V

Heparin-precipitable fraction values in patients with various neoplastic diseases

\begin{tabular}{|c|c|c|c|c|c|c|}
\hline Patient & Age & Type of tumor & $\underset{g m . \%}{\text { HPF }}$ & $\begin{array}{c}\text { Fibrinogen } \\
\text { gm. } \%\end{array}$ & $\underset{m m . / h r}{\text { ESR }}$ & CRP \\
\hline $\begin{array}{r}1 \\
2 \\
3 \\
4 \\
5 \\
6 \\
7 \\
8 \\
9 \\
10 \\
11 \\
12 \\
13\end{array}$ & $\begin{array}{l}7 \mathrm{yr} . \\
7 \mathrm{mo} . \\
7 \mathrm{yr} . \\
54 \mathrm{yr} . \\
68 \mathrm{yr} . \\
10 \mathrm{yr} . \\
9 \mathrm{yr} . \\
4 \mathrm{yr} . \\
9 \mathrm{yr} . \\
13 \mathrm{yr} . \\
7 \mathrm{yr} . \\
8 \mathrm{mo} . \\
6 \mathrm{mo} .\end{array}$ & $\begin{array}{l}\text { Hodgkin's disease } \\
\text { Cavernous hemangioma } \\
\text { Hodgkin's disease } \\
\text { Metastatic carcinoma of the lung } \\
\text { Metastatic' carcinoma of the lung } \\
\text { Acute leukemia } \\
\text { Acute leukemia } \\
\text { Metastatic Wilm's tumor } \\
\text { Jaw sarcoma } \\
\text { Myelogenous leukemia } \\
\text { Disseminated lymphoma } \\
\text { Neuroblastoma } \\
\text { Wilm's tumor }\end{array}$ & $\begin{array}{l}0.83 \\
0.66 \\
0.61 \\
0.55 \\
0.37 \\
0.31 \\
0.29 \\
0.23 \\
0.22 \\
0.19 \\
0.18 \\
0.13 \\
0.13\end{array}$ & $\begin{array}{l}0.67 \\
0.35 \\
0.52 \\
0.58 \\
0.30 \\
0.32 \\
0.37 \\
0.25 \\
0.12 \\
0.27 \\
0.28 \\
0.32 \\
0.32\end{array}$ & $\begin{array}{r}74 \\
49 \\
106 \\
29 \\
22 \\
78 \\
40 \\
26 \\
23 \\
22 \\
40 \\
42 \\
42\end{array}$ & $\begin{array}{l}4+ \\
3+ \\
3+ \\
1+ \\
0 \\
4+ \\
0\end{array}$ \\
\hline
\end{tabular}


seminated, and in whom constitutional manifestations were severe.

Nephrosis. Sixteen of the 21 nephrotic patients studied had normal or low HPF levels, although clottable protein values were frequently very high and CRP was present in the serum. Serial studies during the course of steroid-induced diureses in these patients (Figure 6) failed to demonstrate any significant changes in HPF in spite of abrupt

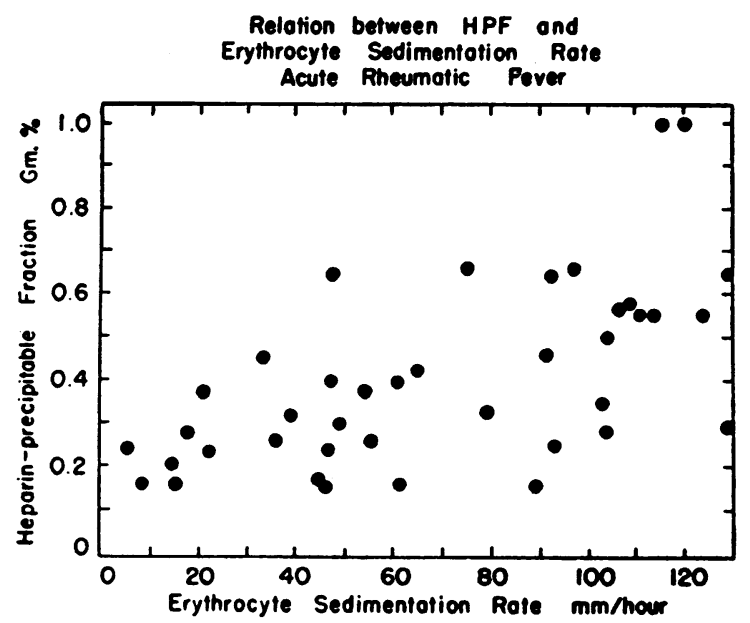

a

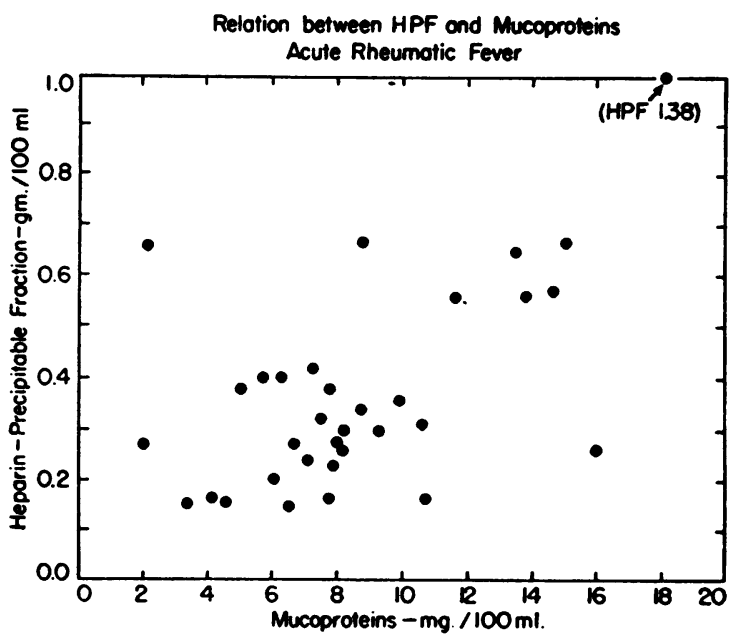

C reduction of ESR, prompt elevation of mucoprotein, and reduction of clottable protein to within normal limits. This mucoprotein change has been observed previously (10).

Pregnancy. Elevated HPF values were found as early as the second month of the first trimester of pregnancy; the levels gradually rose during pregnancy to a maximal value at delivery, and fell to normal about two weeks post partum. Patients

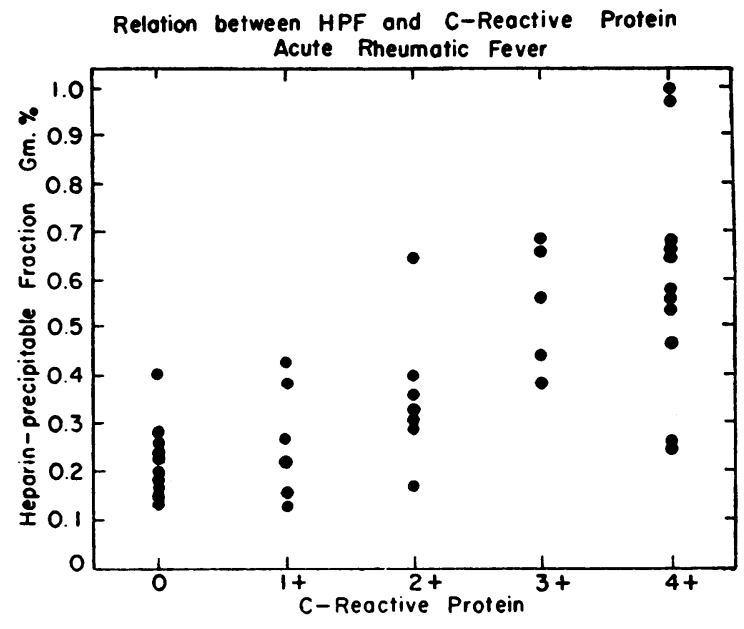

b

Regressions of Heparin-precipitable Fraction on Fibrinogen Values in Normals and Rheumatic Fever Pts.

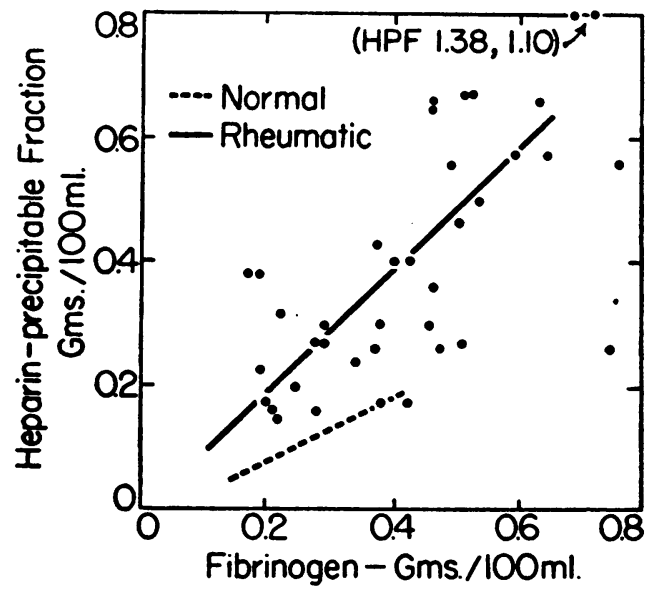

d

Fig. 7 a-d. Correlation Scattergrams Relating hPF Values to Simultaneously Determined ESR, C-Rractive Protein, Mucoprotein, and Fibrinogen Values in 40 Patients Having Acute Rheumatic Fever

Note that a general correlation of the values is shown, but that considerable scatter is evident. In Figure 7d the black line gives the regression of HPF on fibrinogen for the points shown. This should be compared with the similar regression coefficient for 122 normals of similar age represented by the dotted line (points not shown). The slope of the regression lines, as well as the range of values, differs significantly in the two groups. 
with manifestations of pre-eclampsia had higher values than normal women at the same stage of pregnancy. Newborn infants, in contrast to their mothers at term, were found to have very low values, ranging from no measurable level to 0.06 gm. per cent. During the first 72 hours of life, however, these values rose to within the normal range for older infants. These data will be presented in detail elsewhere (11).

Low values were found in patients with severe liver disease and cardiac failure. In both of these conditions the fibrinogen levels were correspondingly lowered. In acute rheumatic fever patients having severe cardiac failure, low values rose to high levels when failure was corrected by appropriate therapy.

\section{Correlation of HPF with other indicators of in- flammatory disease}

The initial HPF values for each of the 40 rheumatic fever patients were compared with simultaneously determined C-reactive protein, erythrocyte sedimentation rate, mucoprotein, and fibrinogen. Correlation scattergrams describing these data are shown in Figures 7 a through 7d.

These scattergrams show a rough correlation between HPF and ESR, CRP and mucoprotein values, as may be seen in the graphic charts depicting values in individual patients. However, they show that normal HPF values were found in some patients with marked elevation of ESR or mucoprotein. The serial changes shown in the nephrotic patient (Figure 6) illustrate clearly the independent variations in the levels of the various acute phase reactions and HPF.

The relation between HPF and simultaneously determined clottable protein values in the rheumatic fever patients is given by the regression diagram in Figure $7 d$, which was constructed from the data of 38 patients on whom simultaneous values were available. The extent and slope of the regression of normal values is significantly different from that of the rheumatic fever patients, corroborating for the group of patients the serial relationship between HPF and fibrinogen previously shown for individual patients.

\section{DISCUSSION}

The data presented in this paper allow a quantitative analysis of the occurrence of a heparin-pre- cipitable, cold-insoluble plasma component in normal individuals and patients with various acute diseases. The method employed routinely for estimating the amount of this component in plasma has proven to be relatively simple and reliable, giving results which are reproducible in replicate samples within $\pm 0.02 \mathrm{gm}$. per cent. Serial daily determinations in individuals with various diseases, and during health, gave data which plotted out smoothly, indicating a degree of day-to-day reliability. Certain possible refinements of the method are suggested by data given in the preceding paper, and these may increase the accuracy of the procedure for further clinical application. The method, as described, appears to be adequate for purposes of delineating the clinical occurrence and physiological significance of the heparin-precipitable component.

In apparently healthy individuals the amount of HPF ranged from 0.04 to $0.27 \mathrm{gm}$. per cent, with mean values varying slightly with age and sex. The generally higher level of HPF in adult females is not explained, although preliminary data indicating that a rise in HPF occurs before and during menstruation may account, in part, for the difference between sexes. It also seems possible that some of the high values, which are responsible for slight skewing of frequency distribution of all data, may be due to the inclusion as normal subjects of individuals having asymptomatic illness not detected by physical examination. The importance of this consideration in interpreting "normal" data describing other "acutephase" phenomena has been stressed in the literature $(9,12)$.

The earliest studies of HPF in humans (2) included only patients with acute rheumatic fever, rheumatoid arthritis, and a few normal adults and infants. As the investigation was broadened it became clear that elevated HPF values were also characteristic of patients having bacterial meningitis or other pyogenic infection, acute streptococcal pharyngitis, or disseminated malignancy. Definitely elevated levels of the fraction thus appear to characterize inflammatory or necrotizing disorders in general rather than any specific disease process. Furthermore, data correlating HPF with the clinical status of the patient indicate that the levels in the plasma are roughly proportional to the severity of the disease under study. There- 
fore, the clinical studies indicate that the occurrence of high levels of a cold-insoluble, heparinprecipitable component in plasma may be added to the long list of so-called "acute-phase" reactions (12) occurring in the circulating blood of acutely ill patients.

The question arises as to the possible practical application of a test for this component of plasma in clinical practice. This study suggests that determination of HPF may provide information at least as valuable as the other non-specific indicators of inflammatory or necrotizing disease. However, no unique advantages of this test over the others are apparent. The requirement of handling at low temperatures would restrict its availability to those laboratories having cold centrifuge facilities, an important practical limitation. Also, the determination is not as simple to perform as the sedimentation rate, fibrinogen, or C-reactive protein determination.

Evidence is presented elsewhere (1) that HPF from human plasma is a protein closely resembling fibrinogen in several chemical and physical characteristics. The observations of low HPF values in patients with liver disease and congestive cardiac failure having low clottable protein values would be in keeping with a close similarity to fibrinogen, perhaps indicating identical or closely related pathways of hepatic synthesis.

Significant differences between HPF and fibrinogen, however, were also encountered. The changing relationships between HPF and fibrinogen values in patients studied serially during disease appear to support the interpretation that HPF does not represent the same physiological entity as fibrinogen itself. During the course of the acute disease process, both HPF and clottable protein values were found elevated. The relative levels of these parameters, however, expressed by the HPF/fibrinogen ratio, changed during recovery in a consistent manner; high ratios of $\mathrm{HPF} /$ fibrinogen in very acute illness returned to low and normal ratios as recovery progressed. Elevated HPF levels appeared earlier in acute illness and fell more rapidly during recovery, in general, than the clottable fraction levels. An alternative interpretation of the high $\mathrm{HPF}$ /fibrinogen ratios during acute illness would be that they reflect marked decrease in the clottability of fibrinogen rather than a relative increase in $\mathrm{HPF}$.
Such a hypothesis is neither supported nor excluded by these data, but deserves further investigation.

The possibility that HPF may, like fibrinogen, play a role in the pathogenesis of fibrinoid lesions has been suggested elsewhere on the basis of observations in experimental animals (13). The question as to its participation in the deposition of fibrinoid in human lesions remains a speculative matter. In some of the conditions characterized by very high HPF values, such as bacterial meningitis, extensive fibrinoid lesions are not commonly observed at necropsy. The observation of very low values in the cases of acute disseminated lupus erythematosus, and in a single instance of polyarteritis, with elevated clottable fibrinogen levels, might be interpreted as indicating that HPF is being continuously depleted as the fibrinoid deposits characteristic of these diseases are being laid down in various organs. The observation in the case of polyarteritis of a progressive decrease in HPF to low levels prior to death, with the development of widespread vascular fibrinoid lesions, would be compatible with this hypothesis. However, the occurrence of abnormally high levels of HPF in acute rheumatic fever and rheumatoid arthritis favors the interpretation that HPF simply represents another inexplicable acute phase reaction. Therefore, no interpretations concerning the role of HPF in disease mechanisms can be made at the present time. Further investigation of the problem along these lines would seem warranted.

\section{SUMMARY AND CONCLUSION}

The occurrence in health and disease and the clinical significance of a protein fraction of human plasma characterized by cold-insolubility in combination with heparin have been studied by means of an empirical technique of measurement sufficiently reliable to allow quantitative interpretation of serial changes in plasma levels. The data allow the conclusions that normal individuals have low levels of the fraction, and that these levels become greatly increased as a result of most acute inflammatory or necrotizing diseases. The appearance of the fraction in increased amounts represents another reaction in the category of "acutephase" phenomena. The data support the other items of evidence indicating that the fraction may 
fulfill a different physiological role from clottable protein. The nature of this function is as yet unrevealed.

\section{ACKNOWLEDGMENT}

The author wishes to express appreciation to the University Hospital Pediatric house staff for help in this study, to Drs. M. D. Olmanson, V. Olmanson, N. Priske, C. Vauble, R. A. Bridges, Mrs. D. Gellerman, and Miss A. Pajerski for assistance, and to Dr. Lewis Thomas for many valuable suggestions.

\section{REFERENCES}

1. Smith, R. T., and Von Korff, R. W., A heparinprecipitable fraction of human plasma. I. Isolation and characterization of the fraction. J. Clin. Invest., 1957, 36, 596.

2. Thomas, L., Smith, R. T., and Von Korff, R., Coldprecipitation by heparin of a protein in rabbit and human plasma. Proc. Soc. Exper. Biol. \& Med., 1954, 86, 813.

3. Weichselbaum, T. E., An accurate and rapid method for the determination of proteins in small amounts of blood serum and plasma. Am. J. Clin. Path., Tech. Suppl., 1946, 10, 40.

4. Markham, R., A steam distillation apparatus suitable for micro-Kjeldahl analysis. Biochem. J., 1942, $36,790$.

5. Saifer, A., and Newhouse, A., Photometric microdetermination of plasma fibrinogen with a thrombin-ninhydrin procedure. J. Biol. Chem., 1954, 208, 159.

6. Morrison, P. R., Preparation and properties of serum and plasma proteins. XV. Some factors in- fluencing the quantitative determination of fibrinogen. J. Am. Chem. Soc., 1947, 69, 2723.

7. Anderson, H. C., and McCarty, M., Determination of C-reactive protein in the blood as a measure of the activity of the disease process in acute rheumatic fever. Am. J. Med., 1950, 8, 445.

8. Winzler, R. J., Devor, A. W., Mehl, J. W., and Smythe, I. M., Studies on the mucoproteins of human plasma. I. Determination and isolation. J. Clin. Invest., 1948, 27, 609.

9. Ham, T. H., and Curtis, F. C., Plasma fibrinogen response in man. Influence of the nutritional state, induced hyperpyrexia, infectious disease and liver damage. Medicine, 1938, 17, 413.

10. Kelley, V. C., Good, R. A., and Glick, D., Mucolytic enzyme systems. XI. Hyaluronidase inhibitor and serum mucoproteins in patients with lipoid nephrosis and acute glomerulonephritis. J. Clin. Invest., 1950, 29, 1500.

11. Smith, R. T., Bridges, R. A., and Olmanson, M. D., $A$ heparin-precipitable fraction of human plasma. III. Changes in the fraction during pregnancy and in the newborn infant (being prepared for publication).

12. Good, R. A., Acute-phase reactions in rheumatic fever. Rheumatic Fever, A Symposium of the Minnesota Heart Association. Minneapolis, University of Minnesota Press, 1952, p. 115.

13. Thomas, L., Smith, R. T., and Von Korff, R., Studies on the generalized Shwartzman reaction. VII. The role of fibrinogen in the deposition of fibrinoid after combined injections of endotoxin and synthetic acidic polymer. J. Exper. Med., 1955, 102, 263. 